\author{
RÁsi Szilvia \\ Eszterházy Károly Egyetem \\ szilviarasi@gmail.com
}

\title{
A CÍM ÉS A KULCSFOGALOM TUDOMÁNYOS SZÖVEGALKOTÁSBAN BETÖLTÖTT SZEREPE
}

\section{Bevezetés}

Az utóbbi időkben az tudományos írás (academic writing) mint kutatási terület, téma egyre nagyobb szerepet kap a tudományos diskurzusban, különösen nemzetközi színtereken (Altinmakas-Bayyurt 2018; Al-Khasawneh 2017; Talebzadeh et al. 2013). Mindazonáltal a tudományos írás szerves részét képező címadással és a kulcsszavak problematikájával mind nemzetközi, mind hazai viszonylatban csekélyebb számú tanulmány jelent meg - a jelenlegi kutatás a hazai szakirodalmat kívánja bővíteni.

A tanulmány egy olyan kísérlet tanulságait mutatja be, amelynek során két absztrakthoz egyetemi oktatóknak és hallgatóknak kellett címet és kulcsszavakat rendelni. A vizsgálat az absztraktok címének nyelvi megalkotottságát, sajátosságait vizsgálja, és azt mutatja be, hogy milyen technikák érvényesülnek a kulcsfogalmak és azok mennyiségi korlátjainak meghatározása során, illetve hogy ezek hogyan függnek össze az oktatói és hallgatói e területen való jártassággal, rutinnal és tapasztalattal.

\section{Tudományos írás}

Magyarországi viszonylatban az anyanyelvi tantárgyak esetében jellemző, hogy a tanárok a fogalmazástanítás során elsődlegesen a retorikus írást tanítják, így a hazai közoktatásban a forrásalapú írás tanítása minimálisra csökkent (Pintér-Molnár 2017). A forrásalapú szövegalkotás a szakirodalmi információkon alapuló írást jelenti, amely a nemzetközi szakirodalomban (Klein-Boscolo 2016; Kirkpatrick 2012) writing from sources-ként terjedt el. Szilassy (2014) egy korábbi kutatásában kimutatta, hogy nagy hiányosságok vannak a leérettségizett, felsőoktatási tanulmányaik elején járó hallgatók szövegalkotási képességeiben. Többek között ennek az az oka, hogy a diákok kommunikációs készségeinek, képességeinek, illetve az írásbeli szövegalkotásuknak fejlesztésére a közoktatásban nincs kellő hangsúly fektetve (vö. Jánk 2016, 2017). Ugyanakkor elvárás és feltétel, hogy a felsőoktatásban tanuló hallgatók tudományos íráskészsége megfelelő legyen ahhoz, hogy tanulmányaik során képesek legyenek jól strukturált, tudományos nyelvezettel megfogalmazott szövegek megalkotására, mint amilyen például a szemináriumi dolgozat, szakdolgozat, diplomamunka. A tudományos szövegszerkesztés az alapja annak a tantárgynak, amely a hallgatók tudományos íráskészségének fejlesztésére alakult ki, és amely a nemzetközi szakirodalomba 
academic writing néven került be. A tantárgy az akadémiai írásra (academic writing) és a tudományos írásra (scientific writing) épül, amelyeknek a kiindulópontját a források felhasználása alkotja. Ezt a két szövegalkotási formát főleg a felsőoktatás és a tudományos élet alkalmazza. A kettő közti különbség az, hogy míg az akadémiai írás során a szerző egy probléma, terület szakirodalmát tanulmányozza, illetve ezzel kapcsolatban újabb gondolatokat, problémákat vet fel (Kruse 2003), addig a tudományos írás során a szerző informálja az olvasót egy konkrét kutatás eredményéről (Sternberg-Sternberg 2010). Bár a két kifejezést sokszor kezeli a szakirodalom szinonimaként, Pintér és Molnár (2017) szerint az oktatásban az akadémiai írás van jelen, mivel a tanulási folyamat során a szakirodalom tanulmányozása az egyik legfőbb cél, ami a szemináriumi dolgozatok írásával hatékonyan fejleszthető, a tudományos írás pedig már inkább a hivatásos tevékenységet jelenti.

Ma már a hazai felsőoktatási intézmények tantárgyainak mintatanterveiben is találkozhatunk olyan kurzusokkal, mühelyekkel, amelyek a tudományos szövegalkotás fejlesztésére irányulnak, például írásgyakorlat, tudományos írás, tanulmányírás, a tudományos közlés mủvészete néven. Ugyancsak változó a fogalom megnevezése a magyarországi szakirodalomban is: tudományos irás (Pintér 2009; Veszelszki 2016; Deli-Rétvári 2018), tudományos szövegalkotás (Rási 2019), tudományos írásmüvek készitése (Kurtán 2011), tudományos szöveg irása (Körtvélyesi 2018). Bár a kurzusok, műhelyek tartalma és célja zömében megegyezik, a nemzetközi gyakorlattal ellentétben a hazai szakirodalomban még nincs a tudományos íráskészség tanításának egységes megnevezése (Pintér-Molnár 2017).

\subsection{Címtípusok és azok funkciói}

A tudományos szövegalkotás szerves részét képezi a cím, az írott szövegek azon része, amellyel az olvasó legelőször találkozik, és amely alapján (gyakran) eldönti, hogy tovább olvassa-e a szöveget vagy sem. Egy jól választott címmel számottevő olvasóhoz juthat el a szöveg, míg egy rosszul megfogalmazott cím miatt vagy olvasókat veszíthet el a szerző, vagy sosem jut el a produktum a célközönséghez (Day 1995). Ezek alapján a cím legfőbb feladatai közé tartozik, hogy odairányítsa a figyelmet a szövegre, hangsúlyozza annak lényegét, kifejezze a szerző attitűdjét a téma iránt, elősegítse a leltározást (Szabó 2001; Tolcsvai Nagy 2001; Tomesz 2015; Domonkosi 2016). A figyelemfelkeltés mellett megjelenik még a cím kataforikus szerepe is, amely lényege, hogy előzetesen informálja az olvasót a hozzá tartozó szövegről (Szikszainé 1999). A cím és a szöveg viszonya lehet metonimikus és deiktikus. Metonimikus viszony akkor lép fel, amikor a cím képviseli a szöveget, deiktikus viszonyról pedig akkor beszélünk, amikor rámutat a szövegre (Tolcsvai Nagy 2001).

Szikszainé (1999) a címek négy általános csoportját állapítja meg: témamegjelölö cím, müfajjelölö cím, címkeszerepü cím, reklámszerepü cím. A témamegjelölö címek a leginformatívabbak, ezekből kiderül a szöveg témája. A címkeszerepủ címekre jellemző, hogy terjedelmüket tekintve rövidek - egy- vagy kétszavasak. Úgy címkézik fel a szöveget, mint az eladásra kínált árut szokás az üzletekben, így viszonylag nagy hangulatkeltő jelleggel 
bírnak. A reklámszerepü címek alapvetően az olvasó figyelmének felkeltésére irányulnak. Ezeknél a címeknél a hatásvadászat az elsődleges, míg az informativitás a perifériára szorul. A műfajmegjelölő címek esetében a cím egyértelműen jelzi az írásmű műfaját. Egyes címek egyértelműen besorolhatók a csoportok valamelyikébe, ám Szabó (2001) szerint az a jó cím, amelyben bizonyos mértékig megjelenik az előbb felsorolt csoportok többsége. Egy-egy cím megalkotását a szöveg témáján kívül természetesen befolyásol(hat)ják egyéb tényezők is, mint például a megjelenés országa, a szöveg müfaja stb.

\subsection{A kulcsfogalmak szerepe}

A tudományos szövegalkotás további lényeges elemei a kulcsszavak, kulcsfogalmak, amelyek szintén megelőzik magát a szöveget, sokszor a rezümészöveget is. Ezek feladata egyrészt tovább fokozni az olvasó érdeklődését a szöveg elolvasása iránt, másrészt még jobban pontosítani a szöveg témáját. Így kulcsfogalomként nem tanácsos megismételni a cím egyes szavait. A kulcsfogalmak mennyiségi korlátja általában folyóirattól, intézménytől, kiadótól stb. függően változhat (Lőrincz-Sturcz 2013), de leggyakrabban 5 környékén mozog, pl. 3-5 (Debreceni Egyetem, Nyitrai Konstantin Filozófus Egyetem, Cambridge Core), 5-7 (Harvard University), 4-6 (Szegedi Tudományegyetem, Pannon Egyetem). A szakirodalom nagyon gyakran felváltva vagy egymás szinonimájaként használja a kulcsszó és a kulcsfogalom kifejezéseket, pedig a kettő nem ugyanaz. A kulcsszó (keywords) egyetlen szót jelent, míg a kulcskifejezés (keyphrases) több szóból álló kifejezés. A kettőt együttesen kulcsfogalomnak (key terms) nevezhetjük, amely lényege, hogy a lehető legtömörebben, legpontosabban és legrövidebben leírja a szöveg témáját vagy a kutatás tárgyát (Siddiqi-Sharan 2015). A kulcsszavak megfogalmazása során tehát egy olyan lényegkiemelési, sürítési technika érvényesül, amely elvezeti az olvasót a szöveghez és informálja az írásmű témájáról.

\section{Diskurzushibridizáció a tudományos szövegek címeiben}

A korábban felsorolt négy címtípust alapvetően két skálán elhelyezve tudnánk a legjobban szemléltetni, ezek az informativitás skálája és a figyelemfelkeltés skálája. Az előbbi lényege, hogy minél több információt osszon meg az olvasóval a szövegről, míg az utóbbin olyan címtípusok helyezkednek el, amelyek célja az olvasó érdeklődésének, figyelmének felkeltése. A tudományos szövegek címei az informativitás skáláján találhatók, céljuk ugyanis az, hogy tájékoztassák az olvasót a szöveg témájáról, tárgyáról. Napjainkban a tudományos szövegek címei egyre inkább elmozdulni látszanak az informativitástól a figyelemfelkeltés irányába. A szakirodalom ezt a típusú diskurzusvegyülést diskurzushibridizációnak nevezi (Fairclough 1992, 1993; Eitler 2011, 2012; DomonkosiLudányi 2018: 101). Azon a címen, amely megfelelően informatív, de már kellően figyelemfelkeltő, megfigyelhető a diskurzushibridizáció jelensége. A diskurzushibridizáció legfőbb összetevői közé tartozik az olyan típusú diskurzusvegyülés, amely során a nem társalgási stílus jellegzetességei vegyülnek a társalgási stílussal, valamint a nyelv 
informalizálódása is. A nyelv informalizálódása többek között a tegezésben, felszólító mód használatában, az informális stílusú szavak alkalmazásában és a morfológiailag egyszerűsített változatok alkalmazásában jelenik meg (Eitler 2011).

\section{Minta és módszer}

Jelen vizsgálat egyetemi oktatók és hallgatók címadási szokásait vizsgálta. A minta teljes száma 107, amiből 89,70\% (96 személy) tanár szakos hallgató, 10,30\% (11 személy) pedig oktató, akik véletlenszerủ mintaválasztási módszerrel kerültek be a vizsgálatba. Az adatközlők az egri Eszterházy Károly Egyetem Bölcsészettudományi és Művészeti Karának Nyelv- és Irodalomtudományi Intézetében tanulnak, oktatnak. Az adatközlők tudományos munkáinak száma a következőképpen oszlik meg: 6,54\% (7 személy) írt 30-nál több tudományos munkát; 2,80\% (3 személy) 10-29 között; 3,74\% (4 személy) 4-9 között; 86,92\% (93 személy) pedig 0-3 között. Az adatokból egyértelműen kiolvasható, hogy a válaszadók zöme nem jártas a tudományos írás területén.

Az adatok kérdőíves módszerrel gyűltek össze, amely két fő részből állt: az anonim háttérkérdőívet egy olyan rész követte, ahol az adatközlőknek két konkrét absztrakthoz kellett címet és kulcsszavakat írniuk. Az utasításban nem volt megszabva, hogy a cím milyen terjedelmű legyen, mint ahogy az sem, hogy hány darab kulcsfogalmat írjanak. A két absztrakt a Tudománykommunikáció konferencia 2018-as absztraktfüzetéből (Veszelszki-Cser 2018) került be a kérdőívbe, melyek a következők:

(1) Közel másfél évtizede indítottuk a www.csillagaszat.hu híroldalt a tudós szakma és a kapcsolódó civil szféra együttmüködésében. A Magyar Csillagászati Egyesület hírportáljaként működő oldalon egyetemi és akadémiai oktatók, kutatók, kisebb arányban egyetemi hallgatók írásai jelennek meg, jellemzően heti 4-5 csillagászati cikk formájában. Az előadásban bemutatjuk a hosszú távú működést lehetővé tevő legfontosabb tényezőket, a tapasztalatokat a sajtóval való együttműködés lehetőségeiről, illetve bátorítjuk más szaktudományok képviselőit hasonló kezdeményezések elindítására (Kiss 2018: 17).

(2) Mit tehet egy 21 éves fiatal azért, hogy nála alig néhány évvel fiatalabb társai jobban szeressék a természettudományokat? Hogyan taníthatja meg a 10-16 éves gyerekeket, hogy mit higgyenek el, és mit ne; honnan ismerhetik fel, ha valami áltudomány, és honnan, ha valami valódi tudomány? Hogyan lett egy kezdeti, „természettudományokat fogok népszerüsíteni nagykoromban” álomból valóság? Előadásomban szeretnék választ adni e kérdésekre; bemutatni, hogyan alakult ki tudománynépszerüsítő csapatunk (tupim.ga), illetve felvázolom azokat az innovatív megoldásokat, amelyekkel népszerűsítjük a természettudományokat. Tudománynépszerüsítő munkám mellett nagy hangsúlyt fektetek 
arra is, hogy a fiatal korosztállyal megismertessem azokat a problémaköröket, melyekről az iskolában nem vagy csak keveset hallanak, mégis mire felnőnek égető kérdések lesznek (pl. robotok jogairól szóló kérdések, energia elóállításának kérdése stb.). Előadásomban ismertetem, milyen módszerekkel lehet fejleszteni a diákok soft-skilljeit, hogy készen álljanak ezen kérdések megválaszolására (Molnár 2018: 22).

A kérdőíveket az oktatók online, míg a hallgatók hagyományos nyomtatott verzióban kapták meg. A nyomtatott verzió - többek között - azért bizonyult hatékonynak, mivel így nyomon követhető volt az adatok alakulásának folyamata, tehát megfigyelhető lett, hogy milyen változásokon ment át egy-egy cím, mire végleges állapotba került.

\section{Eredmények}

A következőkben a vizsgálatban összegyüjtött adatok kerülnek ismertetésre. Elöször a címek tartalmi elemzését mutatom be, amit a kulcsfogalmak mennyiségi elemzése követ.

\subsection{Címek elemzése}

Korábban már volt szó arról, hogy a címek négy általános csoportja a témamegjelölö, címkeszerepű, műfajmegjelölő és a reklámszerepű cím. A témamegjelölő címek a leginformatívabb jellegűek, mivel a céljuk, hogy ismertessék az olvasót a szöveg témájával, tartalmával. Olyan címek sorolhatók ebbe a csoportba, mint $A$ csillagászat.hu bemutatása; A természettudományi tudománynépszerüsités perspektivái az oktatásban; A természettudományok népszerüsitése a fiatalok körében. Ezeknél a címeknél a hatásvadászat a háttérbe szorul ellentétben a tájékoztató jelleggel.

A címkeszerepű címek már terjedelmüket tekintve sem lehetnek ennyire informatívak, mint a témamegjelölőek, mivel hosszukat tekintve egy-kétszavas címekről van szó. Ilyen címek például a Hirrhullás; Tudománynépszerüsités; Tehetséggondozás; Tudóspalánták. Rövidségük miatt általában a figyelemfelkeltésre összpontosítanak, mivel egy-két szóban aligha lehet pontosan meghatározni a szöveg témáját.

A műfajmegjelölő címek esetében a címben legtöbbször megjelenik, vagy utalás történik az írásmü műfajára, például $A$ Magyar Csillagászati Egyesület elöadása; Csillagászati hirportál ismertetöje.

A legutolsó a reklámszerepủ címek csoportja, amely a legtávolabb áll a tudományos stílustól, nyelvezettől. Ezek olyan típusú címek, amelyek lényege nem a tájékoztatás, hanem a hatásvadászat, az olvasó figyelmének felkeltése. A reklámszerepű címek olyan technikákat alkalmaznak, amelyek szembetűnők, érdekesek, humorosak lehetnek az olvasó számára. Ezért a vizsgálatban alkalmazott technikák alapján négy alcsoportot alkottunk, amelyek a nyelvjátékos címek, hozott anyagból származó címek, tegező hangnemet alkalmazó címek, felszólító módú címek. 
A nyelvi játékos címekre jellemző, hogy a cím nagyon sokszor csak az írás elolvasás után válik értelmezhetővé (Szabó 2001), mivel a szöveg segíthet a cím megértésében, dekódolásában. A vizsgálatban gyakori volt, hogy az adatközlők az absztraktok kulcsfogalmával alkottak egy-egy nyelvjátékos címet, mint a CsillagÁsz; TUDOM(ány); Csillagászati tervek; Hir csillagok. Ezeknél a címtípusoknál gyakran jelenik meg rövidítés vagy a betürím is. A LOVE TT! esetében nemcsak az idegen nyelv használata figyelhető meg mint figyelemfelkeltő elem, hanem a természettudomány TT-vé való rövidítése, valamint a nagybetűk használata és a mondat végi írásjel is.

A vizsgálatban megjelent a címeknek egy olyan csoportja is, amely az ún. hozott anyagokra épít. Több esetben is adták a Határ a csillagos ég szólást az egyik absztrakt címének, míg az Életrevalók; Csillag születik; Interstellar címeknél a már meglévő, más műfajbeli címek újrafelhasználását figyelhetjük meg. A címek esetében a nyelvjátékokra jellemző továbbá, hogy azonos szótőből különböző végződésű szavakat alkotnak (Szabó 2001) a szerzők, mint például a Természetesen a természettudományokról példa esetében. Ez a cím (is) viszonylag messze került a tudományos stílustól, mint a következő példák is, amelyekben megfigyelhetőek a diskurzushibridizáció nyelvi-informalizációs összetevőjének elemei, a tegezés és a felszólítás. Személyessé válik a szöveg azáltal, hogy a szerző tegezve szólítja meg az olvasót a következő példákban: Álomból valóság - Tudd az igazat; Mit tudsz a csillagokról?; Szeresd meg a tudományokat; Tudd, miböl vagyok! Ez utóbbiban már megjelenik a felszólítás is, amit a tudományos nyelvezet szintén nem alkalmaz, a média, sajtó viszont már annál inkább. További példák: Népszerüsitsük a természettudományokat; Több szót a csillagászatról!.

Mivel a hallgatók nyomtatott kérdőíveket töltöttek ki, így azokon a példákon nagyon jól tetten érhető a diskurzushibridizáció folyamata, mivel látszik, hogy melyek azok a címek, amelyeket első verzióként alkottak, és melyek lettek a véglegesek. Például:

(3) Fermészet és $\rightarrow$ Fanulás a természetröt $\rightarrow$ Tanitó természet

Ebben az esetben a hallgató a legelső verzióban még egy viszonylag informatív címet alkotott, majd ezt kétszer is áthúzva, átfogalmazva egy teljesen legkevésbé informatív változatot jelölt meg véglegesként.

(4) (A magyar csillagászati egyesütet hírportátjárót $\rightarrow$ Hirhullás

A (4) példában az figyelhető meg, hogy az adatközlő egy aránylag tájékoztató címet áthúzva végül egy címkeszerepü címet alkotott - vagyis a tudományos diskurzus ebben az esetben is hibridizálódott. 


\subsection{Kulcsfogalmak elemzése}

Jelen vizsgálatban a kulcsfogalmak fóképp mennyiség alapján kerülnek elemzésre. A kulcsfogalmak mennyiségi korlátjára általában 3-6 jellemző. Tartalmukat tekintve a lényegük, hogy a lehető legtömörebben, legpontosabban és legrövidebben jelöljék a szöveg témáját vagy a kutatás tárgyát. Jelen vizsgálat kérdőívében nem jelöltük a kulcsfogalmak mennyiségének korlátait, az adatközlőktől függött, hogy ők maguk mennyit jelöltek meg. Mivel nagy különbség volt a kulcsfogalmak számának esetében a hallgatók és oktatók között, ezért a következőkben az adatokat külön tárgyaljuk. Az (1) absztrakthoz 11 oktatóból 18,18\% (2 oktató) két fogalmat; 18,18\% (2 oktató) három fogalmat; 63,64\% (7 oktató) pedig négy fogalmat írt. A hallgatók esetében már megjelent az öt, hat hét és a nyolc kulcsfogalom is. Ez a megoszlás a 96 hallgató adatai alapján a következőképpen néz ki: egy fogalom 6,25\% (6 hallgató); két fogalom 19,79\% (19 hallgató); három fogalom 35,41\% (34 hallgató); négy fogalom 20,83\% (20 hallgató); öt fogalom 8,33\% (8 hallgató); hat fogalom 3,13\% (3 hallgató); hét fogalom 4,17\% (4 hallgató); nyolc fogalom 2,08\% (2 hallgató).

A (2) absztrakt esetében 11 oktatóból 72,73\% (8 oktató) írt három fogalmat; 18,18\% (2 oktató) négy fogalmat; 9,09\% (1 oktató) pedig öt kulcsfogalmat. Míg a 96 hallgató körében a kulcsfogalmak határa 1-12 volt, amely a következőképpen oszlik meg: egy fogalom 10,41\% (10 hallgató); két fogalom 17,71\% (17 hallgató); három fogalom 39,58\% (38 hallgató); négy fogalom 10,41\% (10 hallgató); öt fogalom 9,37\% (9 hallgató); hat fogalom 3,13\% (3 hallgató); hét fogalom 2,08\% (2 hallgató); nyolc fogalom 3,13\% (3 hallgató); kilenc fogalom 2,08\% (2 hallgató); tíz fogalom 1,04\% (1 hallgató); tizenkét fogalom $1,04 \%$ (1 hallgató).

Az adatok azt mutatják, hogy az oktatók az (1) absztrakthoz 2-4 kulcsfogalmat írtak, a hallgatóknál ez a határ már 1-8 volt. Hasonlóképpen volt a (2) absztrakt esetében is, ahol az oktatók 3-5 kulcsfogalmat írtak, a hallgatók pedig 1-12-t. Ezek az adatok arra utalnak, hogy az oktatók következetesebben írnak azonos számú kulcsfogalmat, míg a hallgatók kevésbé. Bár jelen elemzésnek nem célja a kulcsfogalmak tartalmi elemzése, alapvetően mégis megfigyelhetőek oktatók és hallgatók kulcsfogalmai közti különbségek. Az oktatók esetében egyszer sem fordult elő, hogy a szavak ragozott alakját használták volna, míg a hallgatók esetében gyakran volt erre példa: kezdeményezésre, hírportáljaként, innovativ megoldásokat, hasonló kezdeményezések elinditására. Az oktatók példáiban nem volt utalás műfajra, míg a hallgatóknál igen: összefoglalás, elöadás. Míg az oktatók az absztraktok lényeges elemeit emelték ki, addig a hallgatók nagyon gyakran az irreleváns, lényegtelen fogalmakat jelölték meg, például robotok jogai, NASA, robotika. Ezekre az adatokra nézve arra következtethetünk, hogy a hallgatóknak nem volt teljesen világos a kulcsszó fogalom, mivel nagyon gyakran sem terjedelmileg, sem tartalmilag nem feleltek meg a tudományos stílusnak. 


\section{6. Összegzés}

$\mathrm{Az}$ adatok összességében azt mutatják, hogy a címadásban erőteljesen jelen van a diskurzushibridizáció, mivel a tudományos címek elmozdultak a figyelemfelkeltés irányába. A hallgatók címadási szokásain érezhető, hogy a tudomány területén járatlanok, míg a média sokkal nagyobb szerepet kap az életükben, így a média nyelvhasználatából sokkal gyakrabban, könnyedebben emelnek át szokásokat, mint a tudományéból. Éppen ezért a hallgatóknak ezeket a tapasztalatokat tanítani is kellene amellett, hogy tudat alatt elsajátítanak bizonyos szokásokat a tudományos szövegek olvasása során. Mindenképpen megfontolandó, hogy bekerüljön a hallgatók képzési programjába az academic writing tantárgy, ahol olyan ismereteket sajátíthatnának el, mint például a címadás, kulcsszavak kiválasztása, absztraktok megírása, megfelelő hivatkozás, releváns szakirodalom kiválasztása, stb.

\section{Források}

Kiss László 2018. csillagászat.hu: tapasztalatok egy tudományos ismeretterjesztő hírportállal. In: Veszelszki Ágnes - Cser Nóra (szerk.): Tudománykommunikáció konferencia: absztraktkötet. Budapest: Budapesti Corvinus Egyetem Magatartástudományi és Kommunikációelméleti Intézet. 17.

Molnár Janka Sára 2018. Tudomány nélkül mit érek én? In: Veszelszki Ágnes - Cser Nóra (szerk.): Tudománykommunikáció konferencia: absztraktkötet. Budapest: Budapesti Corvinus Egyetem Magatartástudományi és Kommunikációelméleti Intézet. 22.

Veszelszki Ágnes - Cser Nóra (szerk.) 2018. Tudománykommunikáció konferencia: absztraktkötet. Budapest: Budapesti Corvinus Egyetem Magatartástudományi és Kommunikációelméleti Intézet.

\section{Irodalom}

Al-Khasawneh, Fadi Maher 2017. A genre analysis of research article abstracts written by native and non-native speakers of English. Journal of Applied Linguistics and Language Research 4/1: 1-13.

Altinmakas, Derya - Bayyurt, Yasemin 2018. An expanatory study on factors influencing undergraduate students' academic writing practices in Turkey. Journal of English for Academic Purposes 37: 88-103. https://doi.org/10.1016/j.jeap.2018.11.006

Day, A. Robert 1995. How to write \& publish a scientific paper? 4th edition. Canada: Cambridge University Press.

Deli Eszter - Rétvári Márton 2018. Academic Writing: A tudományos írás céljai és problémái. Jel-Kép 4: 63-70. https://doi.org/10.20520/JEL-KEP.2018.4.63

Domonkosi Ágnes 2016. A metonimikusság szerepe a sajtónyelvi címadásban. In: Reményi Andrea Ágnes - Sárdi Csilla - Tóth Zsuzsa (szerk.): Távlatok a mai magyar alkalmazott nyelvészetben. Budapest: Tinta Könyvkiadó. 503-510. 
Domonkosi Ágnes - Ludányi Zsófia 2018. Írásbeli kapcsolattartás a hallgató-oktató viszonyban: szokásrendek és problémák a nyelvi reflexiók tükrében. Acta Universitatis De Carolo Eszterházy Nominatae, Sectio Linguistica Hungarica XLIV: 89-107.

Eitler Tamás 2011. Fogyasztói diskurzusok a magyar felsőoktatásban: egyetemi website-ok multimodális elemzése. In: Boda István Károly-Mónos Katalin (szerk.): Az Alkalmazott Nyelvészet Ma: Innováció, Technológia, Tradíció. Budapest, Debrecen: MANYE, Debreceni Egyetem. 162-168.

Eitler Tamás 2012. Egyetemi online bemutatkozó filmek elemzése: a London Metropolitan University példája. In: Molnár Katalin (szerk.): Az alkalmazott nyelvészet regionális és globális szerepe. Szombathely: MANYE. 197-204.

Fairclough, Norman 1992. Discourse and social change. Cambridge: Polity Press.

Fairclough, Norman 1993. Critical discourse analysis and the marketisation of public discourse: the universities. Discourse and Society 4: 133-168. https://oi.org/ 10.1177/0957926593004002002

Jánk István 2016. Az Oktatáskutató és Fejlesztő Intézet digitális tananyagairól. Iskolakultúra 26/5: 12.

Jánk István 2017. Mi az a PISA-sokk, és mi ez a sok felhajtás körülötte? Nyelv és Tudomány. https://www.nyest.hu/hirek/mi-az-a-pisa-sokk-es-mi-ez-a-sok-felhajtas-korulotte (2019. 05. 11.)

Kirkpatrick, Lori C. 2012. Students' strategies for writing arguments from online sources of information (Unpublished doctoral dissertation). London, Ontario, Canada: The University of Western Ontario.

Klein, Perry D. - Boscolo, Pietro 2016. Trends in research on writing as a learning activity. Journal of Writing Research 7/3: 311-350. https://doi.org/10.17239/jowr-2016.07.03.01

Körtvélyesi Zsolt 2018. Bevezetés a tudományos szöveg irásába. Szakdolgozatirók kézikönyve. Budapest: ELTE Eötvös Kiadó.

Kurtán Zsuzsa 2011. Pedagógiai nyelvhasználat tudományos szövegekben. Iskolakultúra 21/10-11: 8-17.

Kruse, Otto 2003. Getting started: academic writing in the first year of a university education. In: Björk, Lennart - Bräuer, Gerd - Rienecker, L. - Jörgensen, Peter Stray (eds.): Teaching academic writing in European higher education. Dordrecht: Kluwer Academic Publishers. https://doi.org/10.1007/0-306-48195-2_2

Lőrincz Éva Anna - Sturcz Zoltán 2013. Prezentáció. Budapest: Typotex Kiadó.

Pintér Henriett 2009. Az írásbeli szövegalkotás: út a tudáshoz. Magyar Pedagógia 109/2: $121-147$.

Pintér Henriett - Molnár Pál 2017. A forrásokra építő tanuláscélú írás: a forrásalapú írás. Magyar Pedagógia 117/1: 29-48. https://doi.org/10.17670/MPed.2017.1.29

Rási Szilvia 2019. A címadás problematikája és a tudományos szövegalkotás oktatása az IPOO-modell alapján. OxIPO interdiszciplináris tudományos folyóirat 1/3: 25-38. https://doi.org/10.35405/OXIPO.2019.3.25 
Siddiqi, Sifatullah-Sharan, Aditi 2015. Keyword and Keyphrase Extraction Techniques: A Literature Review. International Journal of Computer Applications 109/2: 18-23. https://doi.org/10.5120/19161-0607

Sternberg, Robert J. - Sternberg, Karin 2010. The psychologist's companion: A guide to writing scientific papers for students and researchers. New York, NY: Cambridge University Press. https://doi.org/10.1017/CBO9780511762024

Szabó Katalin 2001. Kommunikáció felsőfokon. Budapest: Kossuth Kiadó.

Szilassy Eszter 2014. Egy felsőoktatási szövegalkotási felmérés tanulságai. Anyanyelv-pedagógia 7/3. http://www.anyanyelv-pedagogia.hu/cikkek.php?id=528

Szikszainé Nagy Irma 1999. Leíró magyar szövegtan. Budapest: Osiris Kiadó

Talebzadeh, Hossein - Samar, Reza Ghafar-Kiany, Gholam Reza-Akbari, Ramin 2013. Steps to a Successful Abstract: A Comparative Genre Analysis. The International Journal of Humanities 20/3: 1-25.

Tolcsvai Nagy Gábor 2001. A magyar nyelv szövegtana. Budapest: Nemzeti Tankönyvkiadó.

Tomesz Tímea 2015. A tartalomhoz forma. A tömegkommunikáció szövegfajtái történeti és pragmatikai keretben. Eger: Líceum Kiadó.

Veszelszki Ágnes 2016. Academic Writing, wissenschaftliches Schreiben, tudományos írás. Egyetemi hallgatók írásos produktumai - stilisztikai és grammatikai szempontból. In: Feld-Knapp Ilona (szerk.): Grammatik CM3. Budapest: Eötvös József Collegium. 286-305. 